\title{
Sosyal Medya İletişimi ve Tüketici Temelli Marka Değeri Arasındaki İlişkinin İncelenmesi: Bir GSM Markası Üzerine Tüketici Araştırması \\ (Investigation of the Relationship Between Social Media Communication and Consumer Based Brand Equity: Consumer Research on a GSM Brand)
}

\section{Murat ÇAKIRKAYA iD a, Murat KOÇYİĞİT id b}

${ }^{a}$ Necmettin Erbakan Üniversitesi, Uygulamalı Bilimler Fakültesi, Konya, Türkiye. murat.cakirkaya39@gmail.com

${ }^{\text {bNecmettin Erbakan Üniversitesi, Turizm Fakültesi, Konya, Türkiye. mkocyigit@erbakan.edu.tr }}$

\begin{tabular}{|c|c|}
\hline MAKALE BİLGİSİ & ÖZET \\
\hline $\begin{array}{l}\text { Anahtar Kelimeler: } \\
\text { Sosyal Medya }\end{array}$ & $\begin{array}{l}\text { Amaç - Araştırmanın amacı; sosyal medya iletişimi ile tüketici temelli marka değeri arasında bir } \\
\text { ilişkinin bulunup bulunmadığının tespitidir. }\end{array}$ \\
\hline $\begin{array}{l}\text { Marka Değeri } \\
\text { İnteraktif İletişim }\end{array}$ & $\begin{array}{l}\text { Yöntem - Araştırmanın evrenini, GSM markası Turkcell kullanıcıları oluşturmaktadır. Ancak, araştırma } \\
\text { kapsamında Turkcell marka GSM operatörü kullanıcılarının tamamına ulaşmak zaman kısıtı, maliyet } \\
\text { ve örnekleme ulaşım zorluğundan dolayı, araştırma "Olasılığa Dayalı Olmayan Örnekleme" }\end{array}$ \\
\hline $\begin{array}{l}\text { Gönderilme Tarihi } 25 \\
\text { Mayis } 2019\end{array}$ & $\begin{array}{l}\text { türlerinden "Kolayda Örnekleme Yöntemi" ile gerçekleştirilmiştir. Yapılan analiz kapsamında; } \\
\text { tanımlayıcı istatistiklere yer verilmiş, sosyal medya iletişimi ve tüketici temelli marka değeri ölçekleri } \\
\text { için faktör analizleri gerçekleştirilmiştir. Son olarak sosyal medya iletişimi ve marka değeri alt boyutları }\end{array}$ \\
\hline Revizyon Tarihi 4 Eylül & korelasyon analizi yapılarak çikan sonuçlar yorumlanmıştır. \\
\hline $\begin{array}{l}2019 \\
\text { Kabul Tarihi } 10 \text { Eylül } 2019\end{array}$ & $\begin{array}{l}\text { Bulgular - Gerçekleştirilen korelasyon analizi sonucunda sosyal medya iletişiminin alt boyutları ile } \\
\text { tüketici temelli marka değeri arasında orta kuvvette ve anlamlı ilişkilerin olduğu tespit edilmiştir. }\end{array}$ \\
\hline $\begin{array}{l}\text { Makale Kategorisi: } \\
\text { Araştırma Makalesi }\end{array}$ & $\begin{array}{l}\text { Tartışma - Günümüzde dünya nüfusunun yarıdan fazlası internet kullanmaktadır ve sosyal medya } \\
\text { kullanım oranı \% } 45^{\prime} \text { lere ulaşmıştır. Buna bağlı gelişen sosyal medya iletişimi hem pazarlama içeriğinin } \\
\text { hem de şirket ile müşteriler arasındaki etkileşimin önemli değişimlere uğramasına yol açmıştır. } \\
\text { Müşterilerin kendi aralarında ve müşterilerle şirketler arasında interaktif etkileşim kanallarınn } \\
\text { oluşması da bu trendin bir neticesidir. Bu kanallar geleneksel kanallardan daha büyük etkinliğe sahiptir. } \\
\text { Çünkü etkileşimin, paylaşımın ve geri bildirimin esas olduğu bu iletişim platformları, düşüncelerin } \\
\text { daha kolay ve hızlı bir şekilde paylaşımını sağlamaktadır. Markanın pazardaki gücünü yansıtan marka } \\
\text { değeri de doğal olarak bu etkileşim türünden etkilenmektedir. Sosyal medya platformlarında kurgusu } \\
\text { doğru şekilde oluşturulmuş etkin bir interaktif iletişim, tüketicilere ait marka değer algılarını olumlu } \\
\text { yönde etkileyecektir. }\end{array}$ \\
\hline
\end{tabular}

\begin{tabular}{ll}
\hline ARTICLE INFO & ABSTRACT \\
\hline $\begin{array}{l}\text { Keywords: } \\
\text { Social Media } \\
\text { Brand Equity } \\
\text { Interactive Communication }\end{array}$ & $\begin{array}{l}\text { Objective - The aim of the study is to determine whether there is a relationship between social media } \\
\text { communication and consumer-based brand equity. } \\
\text { Design/methodology/approach - GSM brand Turkcell users constitute the universe of the study. } \\
\text { However, it is not possible to reach all Turkcell brand GSM operator users due to some limitations (time } \\
\text { constraint, cost and sampling difficulties) and the research has been carried out by means of purposive } \\
\text { sampling method which is among the improbable (non-probability) sampling types. Within the scope } \\
\text { of the analysis, descriptive statistics were presented and factor analyzes were conducted for social } \\
\text { media communication and consumer-based brand equity scales. Finally, social media communication } \\
\text { Received 25 May 2019 } \\
\text { Revised 4 September 2019 } \\
\text { Accepted 10 September } \\
\text { and9 }\end{array} \quad \begin{array}{l}\text { Findings - As a result of the correlation analysis, it was found that there was a moderate and significant } \\
\text { relationship between the sub-dimensions of social media communication and consumer-based brand } \\
\text { equity. } \\
\text { Discussion - Today, more than half of the world's population is using the Internet and the rate of social } \\
\text { media use has reached 45\%. Social media communication has led to significant changes in both } \\
\text { mesearch Article }\end{array}$ \\
$\begin{array}{l}\text { marketing content and interaction between the company and customers. The formation of interactive } \\
\text { interaction channels between customers and between customers and companies is a result of this trend. } \\
\text { These channels have greater efficiency than conventional channels. Because these communication } \\
\text { platforms, where interaction, sharing and feedback are essential, make the ideas easier and faster to } \\
\text { share. The brand equity that reflects the strength of the brand in the market is naturally affected by this } \\
\text { type of interaction. An effective interactive communication, whose fictions are correctly constructed on } \\
\text { social media platforms, will positively affect the brand equity perceptions of consumers. }\end{array}$
\end{tabular}




\section{Giriş}

Geleneksel olarak; okumak, izlemek, ürün ve hizmet satın almak vb. amaçlarla kullanılan internetin günümüzde kullanım amacı oldukça farklılaşmıştır. Yukarıdaki amaçlarla interneti kullanan tüketiciler günümüzde içerik paylaşım siteleri, blog'lar, sosyal ağlar ve wiki'ler gibi platformları da sıklıkla kullanmaya başlamışlardır. Tüm bu platformlar bir şirketin itibarını, satışını ve hatta hayatta kalmasını önemli ölçüde etkileyebilen sosyal medya araçlarıdır (Kietzmann vd., 2011: 241).

Müşterilere ürün ve hizmet pazarlamak için sunulan teklifler ve benzer iletişim yaklaşımlarıyla karşılaştırıldığında, sosyal medya kullanımı şirketlerin müşterilerine değer katmak için kullanabileceği yeni ve etkili bir yaklaşım haline gelmiştir (Zauner vd., 2012: 688).

İnternet iletişimi sayesinde bireyler günlük hayatta karşı karşıya kaldıkları tüm sorunları yakınlarıyla paylaşabildikleri gibi alışveriş deneyimlerini de üçüncü kişilerle paylaşabilmektedirler (Jeong ve Jang, 2011: 356).

Markanın pazardaki rekabet gücünü yansıtan önemli belirleyicilerden biri de marka değeridir. Çünkü bir şirketin ürün ve hizmetleri vasıtasıyla müşterilerine sağladığı değer, ilgili markanın ismiyle, logosuyla ya da sembolleriyle birlikte algılanmaktadır (Koçak ve Özer, 2004: 192). Marka değeri bir başka bakış açısına göre ise tüketicilerin markaya atfettikleri değere bağlıdır ve rakip markalar karşısında markanın mali gücünü gösteren sayısal bir değer olarak kabul edilmektedir. Nihayetinde marka değerinin, tüketici eksenli bir kavram olduğunu söylemek mümkündür (Firat ve Badem, 2008: 211).

Marka değeri, bir markanın adı ve sembolleri ile ilişkili aktif ve pasiflerin bir toplamıdır. Markanın sunduğu ürün ve hizmetlerin, bu değerin artmasında ya da eksilmesinde belirleyicidir (Aaker, 1992: 125). Bir markanın önemi, pozitif ilişkilerin şirket ve müşteriler için değer yaratmasından gelmektedir. Yüksek marka değerine sahip kurumlar, ürünlerini/hizmetlerini öngördükleri fiyattan satabilirler, esnek olmayan fiyat hassasiyetine sahip müşterilere sahip olabilirler, yüksek pazar paylarına erişebilirler ve yeni ürün kategorileri sunmaları durumunda başarı elde edebilirler (Nigam, 2012: 82). Bu itibarla markalar, sahiplerine ekonomik ve stratejik değer katmaları nedeniyle müşterilerin ardından, bir şirketin sahip olabileceği en önemli ikinci varlıkları konumundadır (Alhaddad, 2015: 74).

Yapılan çalışmada temel amaç sosyal medya iletişimi ve tüketici temelli marka değeri arasındaki ilişkinin bir GSM markası üzerinden incelenmesidir. Bu kapsamda önceki dönemde bazı sosyal medya kanalları (Facebook vb.) ile marka değeri arasındaki ilişkiye yönelik çalışmalar bulunmakta ise de Türkiye özelinde tüm sosyal medya platformları ile tüketici temelli marka değeri arasındaki ilişkiye yönelik akademik bir çalışmaya rastlanmamıştır. Yapılan çalışma da bu boşluğu gidermeye yönelik olarak gerçekleştirilmiştir. Diğer yandan hem sosyal medya kullanımının hem de tüketiciler üzerindeki etkisinin her geçen gün arttığı, yapılan pek çok araştırma ile ortaya konulmuştur (Colicev vd., 2018: 1). Yine sosyal medyanın marka değeri ile etkileşiminin genel olarak pozitif yönlü olduğu da sonuç bölümünde paylaşılan araştırma örnekleri ile ortaya konulmuştur. Dolayısıyla yapılan araştırmanın hem pazarlama profesyonelleri hem de konuya ilişkin çalışmalarda bulunan akademisyenler için katkı sağlayacağı düşünülmektedir. Şirketlerin sosyal medya iletişimlerini güçlendirme adına daha fazla yatırım yapmaları ve bu yönde gayret sarf etmeleri durumunda marka değerlerinde de pozitif yönlü bir yükseliş söz konusu olacaktır. Bunun sağlanması durumunda, tüketicilerin marka farkındalığı ve markaya duydukları güven artacak bu da beraberinde marka sadakatini getirecektir. Gelişen marka sadakati de fiyata karşı duyarlılığı azaltarak şirket karlılığını artıracaktır.

Aşağıdaki bölümde, konuya ilişkin literatür incelenecek ve sosyal medya pazarlaması bağlamında interaktif iletişimin marka değeriyle ilişkisine dair kavramsal bir çerçeve paylaşılacaktır.

\section{Kavramsal Çerçeve}

\subsection{Sosyal Medya Bağlamında İnteraktif İletişim}

Reklam yapımcıları ve marka yöneticileri, bir iletişim aracı olarak online platformlara dikkat çekmektedirler. Çünkü bu platformlarda etkileşim daha fazladır. Nitekim konuya ilişkin bir çalışmada reklam etkileşiminin; online reklamlara, web sitesine ve reklamda yer alan ürüne yönelik tüketici tutumlarını önemli ölçüde etkilediği sonucuna ulaşılmıştır (Campbell ve Wright, 2008: 62). Ek olarak, çevrimiçi reklamcılık, geleneksel reklamlardan daha bilgilendirici ve güvenilir olarak kabul edilir (Tsang vd., 2004: 67). Bu yeni teknoloji 
çağında, online medya platformlarının önemi her geçen gün artmaktadır. Kullanıcılara ulaşmak ve etkileşimde bulunmak için en büyük potansiyele sahip iletişim ortamlarından biri de sosyal medya platformlarıdır (Hanna vd., 2011: 272).

Özetle kurumun, markanın ya da ürünün tanıtımında sosyal medya araçlarının kullanımı (Barefoot ve Szabo, 2010: 13) olarak tanımlanabilecek olan sosyal medya pazarlamasına dair literatürde çeşitli tanımlar yapılmıştır. Sosyal medya pazarlamasına ait en kapsayıcı tanımlardan biri Tuten'e (2008: 19) aittir. Tuten, sosyal medya pazarlamasını iletişim amaçlarını gerçekleştirmek ve markalaşmayı sağlamak maksadıyla sosyal ağları, sanal dünyaları, sosyal haber sitelerini ve sosyal fikir paylaşım sitelerini içine alan sosyal toplulukların kültürel bağlamda kullanıldığı bir çevrimiçi reklam ortamı olarak tanımlamıştır. Ürün, hizmet ve markanın çevrimiçi ortamda bilinilirliği ve görünürlüğünün artırılmasına olanak sağlayan sosyal medya pazarlaması, aynı zamanda interaktif pazarlamanın ve dolayısıyla interaktif iletişimin de tamamlayıcısı konumundadır (Kelly, 2007: 148-149).

Sosyal medyada gerçekleştirilecek pazarlama faaliyetlerinin boyutları aşağıda sıralanmıştır:

- Online Topluluklar: Bir şirket, sosyal medyayı ürün ve hizmetleri etrafında bir topluluk oluşturmak için kullanabilir. Hareketli topluluklar sadakat yaratır ve iş geliştirmeye katkıda bulunabilecek tartışmaları teşvik eder (Taprial ve Kanwar, 2012).

- Etkileşim: Bir Facebook sayfası veya Twitter hesabı, belirli bir konunun takipçilerine hızlı ve eşzamanlı olarak haber verebilir (As'ad ve Alhadid, 2014: 317). Diğer bir ifadeyle sosyal ağ siteleri, güncel ve tüketiciyle ilgili bilgileri yayınlayarak online toplulukla daha fazla etkileşim kurmayı sağlar (Fischer ve Reuber, 2011: 2).

- İçeriğin Paylaşılması: Paylaşma boyutu, bir bireyin bir sosyal medya ortamında içeriği değiştirme, dağıtma ve alma derecesiyle ilgilidir (As'ad ve Alhadid, 2014: 317).

- Erişilebilirlik: Sosyal medyaya kolayca erişilebilir ve kullanımı çok düşük bir maliyet gerektirir ya da hiç maliyet gerektirmez. Sosyal medya kullanımı kolaydır ve herhangi bir özel beceri ya da kullanım bilgisi de gerektirmez (Taprial ve Kanwar, 2012).

- Güvenilirlik: Mesajınızı insanlara açık bir şekilde iletmek, söylediklerinizin veya yaptığınız şeylerin güvenilirliğini sağlamak, hedef kitlenize duygusal bir şekilde bağlanmak, alıcıyı motive etmek ve sadık müşteriler üretmekle ilgilidir. Sosyal medya, tüm işletmelere (büyük veya küçük) ağ kurmaları ve hedef kitlelerine ulaşmaları, doğrudan bağlantı kurmaları ve söyleyeceklerini dinleyerek güven oluşturmaları için çok iyi bir platform sağlar (Taprial ve Kanwar, 2012). Tüketiciler, diğer tüketiciler üzerinde, pazarlamacılardan 22 kat daha güçlü bir ikna edici etki sağlayabilirler (Coursaris vd., 2016: 3547). Markalar, sosyal medya üzerinden oluşturacakları platformlar sayesinde tüketicilerin konuşmalarını teşvik edebilirler.

\subsection{Marka Değeri}

Marka değeri kavramı pazarlama literatürüne ilk kez 1980'lerde girmiş, 90'lı yıllarda ise bu hem bilim adamları hem de pazarlama uygulamacılarından büyük ilgi görmüştür. Daha sonra konuya ilişkin çok sayıda makale ve kitap üretilmiştir. Ve üretilmeye devam edilmektedir (Alhaddad, 2015: 74).

Marka değerini ele alış biçimindeki farklılıklar nedeniyle, yazarlara göre marka değeri tanımları farklılıklar göstermektedir. Buna vurgu yapan Ukkwatte ve Abeysekera, (2015: 154) pazarlama literatüründe marka değeri tanımı konusunda bir anlaşma olmadığını belirtmişlerdir. Bununla birlikte literatürde kabul görmüş tanımlardan biri Aaker (1992: 125) e aittir. Aaker, bir markaya bağlı varlıkların tespitini düşünerek marka değeri için bir tanım geliştirmiştir. Aaker (2001: 165) marka değerini; bir işletmeyle veya işletmenin müşterileriyle ilintili olarak tanımlamıştır. Buna göre marka değeri, mal ve hizmetlerle sağlanan değere eklenen veya o değerden çıarılan, markayla, marka ismiyle veya sembollerle ilişkili varlık ve yükümlülüklerdir.

Marka değeri kavramına gösterilen bu ilginin en önemli nedenleri arasında şunlar bulunmaktadır; güçlü bir marka değerine sahip markalar pazardan daha fazla pay alabilmekte, marka bilinirliklerini ve pazarlama iletişimi etkinliklerini arttırabilmekte ve daha yüksek bir marka sadakati tesis edebilmektedirler. Buna ek 
olarak, yüksek marka değerine sahip olmak yüksek tüketici tercihine ve satın alma niyetine imkân tanımaktadır (Alhaddad, 2015: 74).

Başka bir yazar tarafından marka değeri; algılanan kalite, marka sadakati ve marka imajından oluşan çok boyutlu bir yapı olarak tanımlanmaktadır. Algılanan kalite, marka değerinin temel bir boyutu ve merkezi bir unsurdur. Çünkü bir marka ile ilişkili fonksiyonel faydaları belirler ve bu da marka değerini arttırır. Marka sadakati ise marka değerinin temel bir boyutudur. Marka sadakati, marka ile ilgili olumlu inanç ve tutumları besler. Marka ile ilgili satın alma davranışını tetikler ve marka ile olumlu ve özgün ilişkiler kurulmasını sağlar (Yoo ve Donthu, 2001: 2). Marka değerinin bir başka boyutu marka imajıdır. Tüketicilerin kafasında olumlu ve güçlü bir marka imajı oluşturmak marka değerini güçlendirecektir. Dolayısıyla pozitif bir marka imajı marka seçim olasılığını arttırdığı gibi markayı rekabetçi tehditlerden de koruyacaktır.

Simon ve Sulivan'a (1993: 28) göre, kuruluşların marka değeri kavramını incelemeleri için iki önemli sebep vardır. Bunlardan ilki muhasebe temellidir. Diğer bir ifadeyle kurumun, muhasebe hesaplarında takip etmek istediği bir marka değeri bedeli vardır. Birleşmelerde veya satın alma operasyonlarında bu değer üzerinden işlem yapılır. Dolayısıyla muhasebecilerin marka değerine bakış açıları pazarlama perspektifinden oldukça farklıdır. Marka değerini incelemenin bir diğer nedeni ise pazarlama temellidir. Bu yaklaşım ise marka farkındalığı, marka sadakati, algılanan kalite vb. tüketiciler üzerinde etki oluşturması nedeniyle önemlidir.

Tüm bu çalışmalar göstermektedir ki; güçlü marka değeri, şirketin kendisini pazarda kabul ettirmesine yardımcı olur. Bu da yüksek kar marjlarına ve daha fazla kurumsal iş birliği projelerinin kurulmasına yol açacaktır. Marka değerinin sosyal paylaşım siteleri aracılığıyla doğru biçimde kullanılması da üreticilere, perakendecilere ve markanın tüketicilerine önemli değer katabilmektedir (Nigam, 2012: 85).

Marka değeri tanımına ilişkin bu farklı yaklaşımlar, marka değerini oluşturan boyutlar için de geçerlidir. Farklı yazarlarca belirlenen farklı boyutlar söz konusu ise de marka farkındalığı, algılanan kalite ve marka sadakati genel kabul görmüş boyutlar olarak değerlendirilebilir.

- Marka Farkındalığı; marka isminin akla gelmesi ve bunun kolaylığı ile ilgilidir. Hem markayı tanıma hem de hatırlama üzerine kuruludur (Zahoor ve Qureshi, 2017: 51). İşletmelerdeki marka yönetimleri incelendiğinde öncelikli hedefin marka farkındalığını arttırmak olduğu görülecektir. Marka hem tanınabilir olmalı hem de rakibin sunmadığı ek değerleri müşteriye sunabilmelidir. Bunun nedeni tanınırlığın tek başına yeterli olmamasıdır. Elektronik ortamda marka bilinirliği de online marka iletişimine dahil kullanıcıların markayı hatırlamasını ve marka bilinirliğini açıklamasını ifade etmektedir (Brogi vd., 2013: 4).

- Algilanan Kalite; müşterilerin mal ve hizmete biçtikleri değeri ifade eder ve en önemli satın alma nedenlerinden bir tanesidir (Samsunlu ve Baş, 2016: 344). Online marka iletişimi bağlamında ise algilanan kalite, üyelerin bir markanın beklentilerini yerine getirme kabiliyetinin göstergesidir (Brogi vd., 2013: 4).

- Marka Sadakati; tüketicinin tercih bakımından bir marka için sergilediği olumlu tutumdur. Marka sadakatine bağlı bir müşteri topluluğu, kurumun satış potansiyelinin ve karlılığının öngörülebilirliğine olanak tanır. Ayrıca sadık müşteri grubu kurumun pazarlama maliyetlerini de olumlu yönde etkileyecektir. Şöyle ki; eldeki sadık müşterileri tutmak, yenileri çekebilmekten çok daha az maliyetlidir. Buna ilave olarak rakiplerin piyasaya girmelerinin önündeki en büyük engellerden biri de sadık müş̧erilerin çokluğudur (Gümüş vd., 2013: 95). Online ağızdan ağıza iletişim bağlamında ise marka sadakati, üyelerinin markayı tekrar alma ya da başka bir şekilde kullanmaya devam etme konusundaki taahhüdü olarak tanımlanmaktadır ki bu da ağızdan ağıza iletişimin doğuracağı olumlu davranışlarla ilişkilidir (Brogi vd., 2013:4).

\subsection{Sosyal Medya Bağlamında İnteraktif İletişim \& Marka Değeri Etkileşimi}

Şirketlerin sosyal medya platformlarını kullanmaları onlara interaktif iletişimde, interaktif ürün sunumlarında ve müşteri üzerinde sağlam bir etki yaratarak önemli katkılar sağlar. Ayrıca sosyal medya ağları, sanal alışveriş deneyimi ve etkileşimli pazarlama imkânları sunarak umut verici özellikler ortaya koyabilir (Nair ve Subramaniam, 2012: 8). Nitekim yapılan bir çalışmada; (1) sosyal medya iletişimi ile marka değerinin güvenilirlik ve değer boyutları arasında pozitif bir ilişkinin bulunduğu, (2) Facebook paylaşımları ile marka değerinin boyutlarından biri olan marka imajı arasında pozitif bir ilişkinin bulunduğu, (3) marka 
değerinin güvenilirlik ve değer boyutlarının satın alma niyeti ile pozitif bir ilişkiye sahip olduğu ve son olarak (4) potansiyel fitness kulübü müşterileri ile sosyal medya yoluyla iletişim kurulması durumunda müşterilerin, pazarlama karmasının bazı unsurlarına kayıtsız kalabilecekleri sonuçlarına ulaşılmıştır (Wright, 2015: 97).

Şirket tarafından sosyal medya üzerinden oluşturulan içerik marka imajını önemli ölçüde etkilemektedir. Kullanıcı tarafından oluşturulan içerik ise hem marka farkındalığını ve hem de hedonik marka imajını önemli ölçüde etkiler. Ayrıca, marka farkındalığı ve hedonik marka imajı, satın alma niyetini etkileyen marka tutumuna da yol açmaktadır (Alam ve Khan, 2019: 54). Marka değeri ile hem satın alma niyeti hem de marka sosyal medyasına katılım niyeti arasında da tam ve doğrudan bir ilişki bulunmaktadır. Diğer yandan doğru oluşturulmuş bir marka içeriğinin tüketici tabanlı marka değeri üzerinde pozitif bir etkisi bulunmaktadır (Coursaris vd., 2016: 3546). Sosyal medya kullanımının marka farkındalığı üzerinde de olumlu bir etkisi bulunmaktadır. Nitekim marka farkındalığı marka değerinin diğer boyutlarını da etkiler. Etkileyici bir imaj oluşturmada ağızdan ağıza iletişim de etkileyici bir unsurdur (Stojanovic vd., 2018: 83).

Sosyal medya aracılığıyla gerçekleştirilen pazarlama faaliyetlerinde sponsor firmalar, müşterilerin değer alg1ları üzerinde olumlu bir etkiye sahiptir (Zauner vd. 2012: 689). Nitekim sosyal medyada, marka değeri üzerindeki reklam bilinirliğinin etkisinin belirlenmesine yönelik çalışmada; reklam bilinirliğinin hem marka bilinirliği hem de marka imajı üzerinde etkili olduğu sonucuna ulaşılmıştır (Alhaddad, 2015: 73).

Trend takibi de en önemli sosyal medya pazarlaması aktivitelerinden birisidir. Tüketicilerin nelere ihtiyaç duyduklarını, nelerden etkilendiklerini, nelere tepki verdiklerini bilmeden ya da sosyal medya platformlarına ait yeniliklerden haberdar olmadan başarıya ulaşmak mümkün gözükmemektedir. Nitekim yapılan bir çalışma havayolu tüketicileri için oluşturulacak sosyal medya pazarlaması aktivitelerinin, marka bilinirliği ve marka imajı üzerinde önemli etkilere sahip olduğunu göstermiştir. Diğer bir sonuç da marka bilinirliğinin sadakati önemli ölçüde etkilemesidir. Aynı çalışmada marka imajının online ağızdan ağıza iletişimden de etkilendiği vurgulanmıştır (Seo ve Park, 2018: 36).

Sosyal medyayı kullanarak interaktif iletişimin kontrolünün ne şekilde yapılması gerektiğine yönelik bir çalışma; bireysel kullanıcıların, kontrol için artan bir koruma sağlamaya çalışmasına karşın şirketlerin, işlevsel etkileşimde bulunmaya çalıştıklarını ortaya koymuştur (Zhang, 2015: 670).

\section{Araştırmanın Metodolojisi}

Araştırmanın amacı, sosyal medya iletişimi ile tüketici temelli marka değerinin alt boyutları olan marka sadakati, algılanan kalite, marka bilinirliği/çağırışımı ve genel marka değeri arasında pozitif yönde ve anlamlı bir ilişkinin olup olmadığını tespit etmektir. Bu doğrultuda araştırmanın evrenini, GSM markası Turkcell kullanıcıları oluşturmaktadır. Araştırmanın evreninin Turkcell Markası'na ait GSM operatörü kullanıcıları ile sınırlandırılmasının nedeni; Türkiye sosyal medya marka endeksi SocialBrands, 2017 Eylül verilerine göre GSM operatörleri içerisinde Turkcell markasının sosyal medyayı en iyi kullanan marka olmasındandır (www.boomsocial.com/social-brands, 2017). Ancak, araştırma kapsamında Turkcell marka GSM operatörü kullanıcılarının tümüne ulaşılabilmesi; süre kısıtı içermesi, maliyetinin yüksekliği ve örnekleme ulaşımdaki zorluk nedeniyle araştırma, kolayda örnekleme yöntemi ile Ekim 2017-Kasım 2017 tarihleri arasında yapılmıştır. Araştırmada 431 katılımcıya anket soruları yöneltilmiştir. Buna karşın 14 anket formunda eksikliklerin ve hatalı verilerin bulunması nedeniyle yapılan analizlerde 417 anket formundan yararlanılmıştır. Araştırmada verilerin normal dağılması nedeniyle parametrik testler kullanılmıştır.

Araştırmada birincil verilerin elde edilmesi amacıyla en yaygın veri toplama yöntemlerinden biri olan anket tekniği kullanılmıştır. Araştırmada kullanılan anket formu 2 bölümden oluşmaktadır. Birinci bölümde; Kim vd. (2010), Mangold ve Faulds (2009), Laroche vd. (2012)'nin çalışmalarından derlenerek geliştirilmiş olan "sosyal medya iletişimi" ölçeği ile Yoo ve Donthu (2001) ve Taşkın ve Akat (2010)'ın çalışmalarından uyarlanan "marka değeri" ölçeğinden faydalanılmıştır. İkinci bölümde ise katılımcıların demografik özelliklerini tespite yönelik sorular bulunmaktadır. Ayrıca bu çalışmada ölçek ifadeleri Turkcell markası üzerinden kurgulanmıştır.

GSM operatörü markası Turkcell kullanıcılarının, sosyal medya iletişimi ile ilgili algı ve düşüncelerinin, marka değeri ve alt boyutları üzerindeki etkilerini tespit etmek amacıyla ölçeklerdeki ifadelerin tümü beşli Likert ölçeği kullanılarak ölçeklendirilmiştir (1-Kesinlikle Katılmıyorum; 2-Katılmıyorum; 3-Kararsızım; 4Katılıyorum ve 5-Kesinlikle Katılıyorum). Araştırmaya ait analizler için istatistik paket programları kullanılmıştır. $\mathrm{Bu}$ doğrultuda araştırma sonucunda elde edilen verileri değerlendirmek için tanımlayıcı 
istatistikler, faktör analizi ve Pearson korelasyon analizi kullanılmıştır. Bu analiz yöntemleri ile ölçülen ve sosyal medya iletişimi ile marka değeri alt boyutları arasındaki ilişkileri tespit etmek amacıyla belirlenen araştırma soruları aşağıdaki gibidir:

- Araştırma Sorusu 1: Sosyal Medya İletişimi ile Marka Sadakati arasında pozitif yönde ve anlamlı bir ilişki var midir?

- Araştırma Sorusu 2: Sosyal Medya İletişimi ile Algılanan Kalite arasında pozitif yönde ve anlamlı bir ilişki var midir?

- Araştırma Sorusu 3: Sosyal Medya İletişimi ile Marka Bilinirliği arasında pozitif yönde ve anlamlı bir ilişki var midir?

- Araştırma Sorusu 4: Sosyal Medya İletişimi ile Genel Marka Değeri arasında pozitif yönde ve anlamlı bir ilişki var mıdır?

Araştırma, Konya sınırları içerisinde yaşayan ve Turkcell markasını kullanan tüketiciler üzerinde gerçekleştirilmiştir. Çalışmanın Konya'da gerçekleştirilme nedeni örnekleme ulaşım kolaylığıdır. Bu nedenle araştırma sonuçlarının genellenebilirliğinin ve dışsal geçerliliğinin sınırlı olduğu söylenebilir. Bir diğer sınırlılık ise, araştırmanın sadece sosyal medya iletişimiyle tüketici temelli marka değeri bileşenlerinin alt boyutlarının korelasyonunun tespit edilmesine yönelik yapılmış olmasıdır. Araştırmada sadece Turkcell Markası kullanıcılarından veri toplanmış olması ve ölçek ifadelerinin sadece bu markaya yönelik oluşturulması da bir diğer sınırlılıktır. Yukarıda da değinildiği üzere araştırma sonuçları sadece verilerin toplandığı Ekim 2017-Kasım 2017 ile sinırlıdır.

\subsection{Bulgular ve Yorumlar}

\subsubsection{Katılımcıların Sosyo-Demografik Özellikleri}

Tablo 1'de katılımcların sosyo-demografik verileri yer almaktadır.

Tablo 1. Katılımcıların Sosyo-Demografik Özellikleri $(\mathrm{n}=417)$

\begin{tabular}{|c|c|c|c|c|c|c|c|}
\hline $\begin{array}{l}\text { Demografik } \\
\text { Değişkenler }\end{array}$ & Değer & Frekans & Yüzde & $\begin{array}{l}\text { Demografik } \\
\text { Değişkenler }\end{array}$ & Değer & Frekans & Yüzde \\
\hline \multirow{5}{*}{ Cinsiyet } & Erk & & & \multirow{5}{*}{$\begin{array}{l}\text { Eğitim } \\
\text { Durumu }\end{array}$} & Ortaöğretim & 38 & 9,1 \\
\hline & \multirow{3}{*}{ Kadın } & 290 & 69,5 & & Lise & 111 & 26,6 \\
\hline & & \multirow{2}{*}{127} & \multirow{2}{*}{30,5} & & Üniversite & 245 & 58,8 \\
\hline & & & & & Lisansüstü & 23 & 5,5 \\
\hline & Toplam & 417 & 100,0 & & Toplam & 417 & 100,0 \\
\hline \multirow{7}{*}{ Yaş } & $17-21$ & 90 & 21,6 & \multirow{7}{*}{ Meslek } & Serbest Meslek & 35 & 8,4 \\
\hline & $22-26$ & 145 & 34,8 & & Memur & 86 & 20,6 \\
\hline & $27-31$ & 74 & 17,7 & & İşçi & 29 & 7,0 \\
\hline & $32-36$ & 50 & 12,0 & & Özel Sektör & 74 & 17,7 \\
\hline & $37-41$ & 28 & 6,7 & & Öğrenci & 171 & 41,0 \\
\hline & $42+$ & 30 & 7,2 & & Diğer & 22 & 5,3 \\
\hline & Toplam & 417 & 100,0 & & Toplam & 417 & 100,0 \\
\hline
\end{tabular}

Tablo 1'de de görüldüğü üzere katılımcıların \%69,5'i erkek, \%30,5'i ise kadındır. Katılımcıların yaş aralıkları incelendiğinde 22-26 yaş aralığındaki katılımcıların oranının \%34,8, 17-21 yaş aralığındaki katılımcıların oranının \%21,6 ve 27-31 yaş aralığındaki katılımcıların oranının \%17,7 olduğu görülmektedir. Öte yandan katılımcıların eğitim durumları incelendiğinde, katılımcıların büyük çoğunluğunun $\% 58,8$ ile üniversite mezunu olduğu görülmektedir. Ayrıca katılımcıların meslek bilgileri incelendiğinde ise \%41,0 'inin öğrenci, \%20,6'sının memur ve \%17,7'sinin özel sektör kategorisinde yer aldığı görülmektedir. Katılımcıların \%41 gibi büyük bir yüzdesini üniversite öğrencilerinin oluşturmasının temel nedenleri; nüfus ortalamaları içerisindeki genç nüfusun yüksekliği, Konya merkezinde eğitim gören üniversite öğrenci sayısının fazlalığı ve üniversite öğrencileri arasında sosyal medya kullanımının yüksekliğidir. Bununla birlikte Konya nüfusuna oranla 
M. Çakırkaya - M. Koçyiğit 11/3 (2019) 2027-2039

üniversite öğrenci sayısının \%6.07 (www.drdatastats.com) olması nedeniyle bulunan sonuçların genellenebilirliğinin sınırlı olduğunu söylemek mümkündür.

\subsubsection{Sosyal Medya İletişimi Ölçeği Faktör Analizi}

Sosyal Medya İletişimi ölçeğinin müşterilerce kaç alt boyutta algılandığı, faktör analizi kullanılarak bulunmuştur. Araştırmada kullanılan verilerin faktör analizi için uygunluğunu tespit etmek amacıyla KMO ve Barlett testlerinden faydalanılmıştır.

Tablo 2. Sosyal Medya İletişimi Faktör Yapısı

\begin{tabular}{|c|c|c|c|c|c|}
\hline \multirow{2}{*}{ Faktör } & \multirow{2}{*}{ Madde } & Faktör Yükleri & \multirow{2}{*}{$\begin{array}{c}\text { Cronbach } \\
\text { Alpha }\end{array}$} & \multirow{2}{*}{$\bar{x}$} & \multirow{2}{*}{ Std. S } \\
\hline & & 1 & & & \\
\hline \multirow{8}{*}{ SMİ } & S26 & 870 & \multirow{8}{*}{,941 } & 3,50 & 1,25 \\
\hline & S25 & 864 & & 3,30 & 1,21 \\
\hline & S21 & 862 & & 3,48 & 1,19 \\
\hline & S20 & 850 & & 3,51 & 1,13 \\
\hline & S24 & 832 & & 3,33 & 1,17 \\
\hline & S22 & 831 & & 3,32 & 1,19 \\
\hline & S23 & 824 & & 3,35 & 1,17 \\
\hline & S19 & 794 & & 3,46 & 1,19 \\
\hline \multicolumn{2}{|c|}{ Özdeğer } & 5,661 & & & \\
\hline \multicolumn{2}{|c|}{ Açıklanan Varyans } & 70,766 & & & \\
\hline \multicolumn{2}{|c|}{ Toplam Açılanan Varyans } & 70,766 & & & \\
\hline \multicolumn{2}{|c|}{$\mathrm{KMO}$} & ,924 & & & \\
\hline \multicolumn{2}{|c|}{ Barlett } & $2704,230(\mathrm{sd} .28$ & & & \\
\hline
\end{tabular}

Gerçekleştirilen faktör analizi neticesinde $(\mathrm{KMO}=0,924)$ soru grubunun tamamının faktör analizine uygun olduğu görülmüştür. Diğer yandan münferit olarak her soru da faktör analizine uygundur. Bu ölçüm yapılırken Örnekleme Yeterliliğinin Ölçümü (MSA) yöntemi kullanılmış ve değişkenlerin anti-image korelasyon matrisi gözden geçirilmiştir. MSA değerleri incelendiğinde (Anti-image korelasyon matrisinde yer alan) tüm değişkenlere ait değerlerin 0,50'nin üzerinde olduğu görülmüştür. Gerçekleştirilen faktör analizine göre sosyal medya iletişimi ölçeği katılımcılarca tek boyutta algılanmıştır. Faktör boyutu Sosyal Medya İletişimi (SMI) olarak adlandırılmıştır. Sosyal medya iletişimi ölçeği boyutu ölçeğin toplam varyansının \%70,766'sını açıklamaktadır. Bulunan her bir faktörün kendi içindeki uyumu Cronbach Alpha katsayısı ile ölçülmüştür. Bu katsayı sorular arası korelasyona bağlı uyum değerlerini göstermektedir. Sosyal medya iletişimi ölçeğinin Cronbach Alpha değeri \%60'ın üstünde yer aldığı için faktör yapısının oldukça güvenilir olduğu sonucuna ulaşılmıştır.

\subsubsection{Marka Değeri Ölçeği Faktör Analizi}

Marka Değeri ölçeğinin kaç alt boyutta algılandığını bulabilmek için faktör analizi yapılmıştır. Verilerin faktör analizine uygun olup olmadığı KMO ve Barlett testleri ile test edilmiştir. 
M. Çakırkaya - M. Koçyiğit 11/3 (2019) 2027-2039

Tablo 3. Marka Değeri Faktör Yapısı

\begin{tabular}{|c|c|c|c|c|c|c|c|c|}
\hline \multirow{2}{*}{ Faktör } & \multirow{2}{*}{ Madde } & \multicolumn{4}{|c|}{ Faktör Yükleri } & \multirow{2}{*}{$\begin{array}{c}\text { Cronbach } \\
\text { Alpha }=, 934\end{array}$} & \multirow{2}{*}{$\bar{x}$} & \multirow{2}{*}{ Std. S. } \\
\hline & & 1 & 2 & 3 & 4 & & & \\
\hline \multirow{5}{*}{ MBÇ } & S11 & ,789 & & & & \multirow{5}{*}{,909 } & 3,27 & 1,11 \\
\hline & $\mathrm{S} 12$ & ,785 & & & & & 3,32 & 1,05 \\
\hline & S13 & ,748 & & & & & 3,41 & 1,06 \\
\hline & S9 & 737 & & & & & 3,50 & 1,12 \\
\hline & $\mathrm{S} 10$ & ,734 & & & & & 3,41 & 1,11 \\
\hline \multirow{5}{*}{ GMD } & S16 & & 757 & & & \multirow{5}{*}{868} & 3,60 & 1,04 \\
\hline & S15 & & ,736 & & & & 3,44 & 1,06 \\
\hline & S17 & & 721 & & & & 3,47 & 1,05 \\
\hline & S18 & & ,715 & & & & 3,43 & 1,00 \\
\hline & S14 & & 661 & & & & 3,53 & 1,08 \\
\hline \multirow{4}{*}{ MS } & S1 & & & 858 & & \multirow{4}{*}{854} & 3,96 & 1,07 \\
\hline & S3 & & & 797 & & & 3,89 & 1,00 \\
\hline & S2 & & & ,733 & & & 3,72 & 0,97 \\
\hline & $\mathrm{S} 4$ & & &, 582 & & & 3,61 & 1,03 \\
\hline \multirow{4}{*}{$\mathrm{AK}$} & S7 & & & & ,786 & \multirow{4}{*}{804} & 3,93 & 0,93 \\
\hline & S6 & & & & 727 & & 3,73 & 0,99 \\
\hline & S8 & & & & 663 & & 3,84 & 1,02 \\
\hline & S5 & & & & ,656 & & 3,58 & 1,02 \\
\hline & ğer & 8,500 & 1,507 & 1,335 & 1,152 & & & \\
\hline \multirow{2}{*}{\multicolumn{2}{|c|}{$\begin{array}{l}\text { Açılanan Varyans } \\
\text { Toplam Açılanan }\end{array}$}} & 20,359 & 19,136 & 15,363 & 14,554 & & & \\
\hline & & \multicolumn{4}{|c|}{69,412} & & & \\
\hline \multicolumn{2}{|c|}{$\begin{array}{c}\text { Varvane } \\
\text { KMO }\end{array}$} & \multicolumn{4}{|c|}{,928 } & & & \\
\hline \multicolumn{2}{|c|}{ Barlett } & \multicolumn{4}{|c|}{$4542,853(\mathrm{sd} .153 ; \mathrm{p}=, 000)$} & & & \\
\hline
\end{tabular}

Gerçekleştirilen faktör analizi neticesinde $(\mathrm{KMO}=0,928)$ soru grubunun tamamının faktör analizine uygun olduğu görülmüştür. Diğer yandan münferit olarak her soru da faktör analizine uygundur. Bu ölçüm yapılırken Örnekleme Yeterliliğinin Ölçümü (MSA) yöntemi kullanılmış ve değişkenlerin anti-image korelasyon matrisi gözden geçirilmiştir. MSA değerleri incelendiğinde (Anti-image korelasyon matrisinde yer alan) tüm değişkenlere ait değerlerin 0,50'nin üzerinde olduğu görülmüştür. Ayrıca, faktör analizi neticesinde birden fazla faktör altında birbirine yakın faktör ağırlığına sahip herhangi bir değişkene rastlanmadığı için analize bu şekliyle devam edilmiştir. Faktör analizine göre marka değeri ölçeği katılımcılarca dört alt boyutta algılanmıştır. Faktörler, Marka Bilinirliği/Çağrışımı (1-MBÇ), Genel Marka Değeri (2-GMD), Marka Sadakati (3-MS), Algılanan Kalite (4-AK) olarak adlandırılmıştır. MBÇ faktörü \%20,359, GMD faktörü \%19,136, MS faktörü \%15,363, AK faktörü \%14,554 oranında katkıda bulunarak faktörler ölçeğin toplam \%69,412'sini açıklamışlardır. Bulunan her bir faktörün kendi içindeki uyumu Cronbach Alpha katsayısı ile ölçülmüştür. Bu katsayı sorular arası korelasyona bağlı uyum değerlerini göstermektedir. Sosyal medya iletişimi ölçeğinin Cronbach Alpha değeri \%60'ın üstünde yer aldığı için faktör yapısının oldukça güvenilir olduğu sonucuna ulaşılmıştır.

\subsubsection{Sosyal Medya İletişimi ve Marka Değeri Alt Boyutları Korelasyon Analizi}

Bu bölümde araştırma kapsamında Sosyal Medya İletişimi ve Marka Değeri alt boyutları arasındaki ilişkiler incelenmiştir. Araştırma sorunsalı doğrultusunda oluşturulan araştırma sorularına cevap bulmak amacıyla Pearson Korelasyon Analizi gerçekleştirilmiştir. 
M. Çakırkaya - M. Koçyiğit 11/3 (2019) 2027-2039

Tablo 4. Sosyal Medya İletişimi ile Marka Değeri Alt Boyutları İlişkisi Korelasyon Analizi

\begin{tabular}{|c|c|c|c|c|c|c|}
\hline & & $\begin{array}{c}\text { Marka } \\
\text { Sadakati }\end{array}$ & $\begin{array}{c}\text { Algilanan } \\
\text { Kalite }\end{array}$ & $\begin{array}{c}\text { Marka } \\
\text { Bilinirliliği } \\
\text { Çağrışımı }\end{array}$ & $\begin{array}{l}\text { Genel } \\
\text { Marka } \\
\text { Değeri }\end{array}$ & $\begin{array}{l}\text { Sosyal } \\
\text { Medya } \\
\text { İletişimi }\end{array}$ \\
\hline \multirow{2}{*}{$\begin{array}{l}\text { Marka } \\
\text { Sadakati }\end{array}$} & $\mathrm{r}$ & 1 & & & & \\
\hline & $\begin{array}{l}\mathrm{p} \\
\mathrm{N}\end{array}$ & 417 & & & & \\
\hline \multirow{3}{*}{$\begin{array}{l}\text { Algilanan } \\
\text { Kalite }\end{array}$} & $\mathrm{r}$ &, $571^{* *}$ & 1 & & & \\
\hline & $\mathrm{p}$ &, 000 & & & & \\
\hline & $\mathrm{N}$ & 417 & 417 & & & \\
\hline Marka & $\mathrm{r}$ &, $569^{* *}$ &, $594^{* *}$ & 1 & & \\
\hline Bilinirliliği/ & $\mathrm{p}$ &, 000 &, 000 & & & \\
\hline Çağrışımı & $\mathrm{N}$ & 417 & 417 & 417 & & \\
\hline Genel & $\mathrm{r}$ &, $552^{* *}$ &, $562^{* *}$ & $642^{* *}$ & 1 & \\
\hline Marka & $\mathrm{p}$ &, 000 & ,000 &, 000 & & \\
\hline Değeri & $\mathrm{N}$ & 417 & 417 & 417 & 417 & \\
\hline \multirow{3}{*}{ Sosyal Medya İletişimi } & $\mathrm{r}$ &, $554^{* *}$ &, $539^{* *}$ & $609^{* *}$ & $639^{* *}$ & 1 \\
\hline & $\mathrm{p}$ & 000 & ,000 & 000 & ,000 & \\
\hline & $\mathrm{N}$ & 417 & 417 & 417 & 417 & 417 \\
\hline
\end{tabular}

${ }^{* *}$ Korelasyon 0,001 düzeyinde anlamlıdır.

Gerçekleştirilen korelasyon analizi doğrultusunda bulunan sonuçlar incelendiğinde; sosyal medya iletişiminin marka değeri alt boyutları ile arasında orta kuvvette ve anlamlı ilişkilerin olduğu görülmüştür. Bu doğrultuda sosyal medya iletişiminin marka değeri alt boyutlarından marka sadakati ile $(\mathrm{r}=0,554 ; \mathrm{p}<0,001)$ pozitif yönlü ve anlamlı bir ilişki bulunmaktadır. Sosyal medya iletişiminin, marka değeri alt boyutlarından algılanan kalite değişkeni ile de pozitif yönde $(r=0,539 ; p<0,001)$, anlamlı bir ilişki olduğu tespit edilmiştir.

Ayrıca, sosyal medya iletişiminin, bir diğer marka değeri alt boyutlarından olan marka bilinirliği/çağırışımı ile $(r=0,609 ; p<0,001)$ pozitif yönde ve anlamlı bir ilişkisinin olduğu belirlenmiştir. Sosyal medya iletişiminin marka değeri alt boyutlarının sonuncusu olan genel marka değeri ile $(r=0,639 ; p<0,001)$, pozitif yönde ve istatistiksel olarak anlamlı bir ilişkinin olduğu tespit edilmiştir.

Bu sonuçlar doğrultusunda, markaların online platformlar üzerinde gerçekleştirmiş oldukları sosyal medya iletişiminin, marka değerinin tüm alt boyutları üzerinde orta kuvvetin üzerinde pozitif yönde ve anlamlı ilişkisinin olduğu tespit edilmiştir. Tüm bu bilgiler doğrultusunda araştırma sorunsalı doğrultusunda belirlenen araştırma sorularına pozitif yönde cevaplar alınmıştır.

\section{Tartışma ve Sonuç}

Şirketlerin tüketicilerle kurdukları iletişim, aşamalı olarak dijital kanallara geçmektedir. Bu nedenle dijital kanalların en önemli platformlarından biri olan sosyal medyanın, marka değeri üzerindeki etkilerini anlamak hayati bir konu haline gelmiştir. Tüketicilerin dijital kanalları her geçen gün daha fazla kullanmaları yönündeki bu eğilimin artarak devam edeceği beklendiğinden sosyal medya faaliyetlerinin önemi ve etkisi de her geçen gün artmaktadır (Colicev vd., 2018: 1).

Sosyal medya iletişimi ile marka değeri arasındaki ilişkiye yönelik yapılan araştırmalarda her iki değişken arasındaki ilişkinin genellikle pozitif yönlü olduğu görülmüştür. Diğer bir ifadeyle sosyal medya pazarlaması faaliyetleri marka değerini olumlu yönde etkilemektedir. Şirketler, sosyal medya sayesinde ürün ve hizmetleri ile ilgili olarak çok sayıda takipçi ile iletişim kurulabilmekte, bu da şirketlerin marka değerlerinin artmasına katkı sağlamaktadır (Wright, 2015: 18). Nitekim yapılan çalışmada da benzer sonuçlara ulaşılmış ve araştırma konusu olan GSM şirketinin online platformlar üzerinde gerçekleştirmiş olduğu sosyal medya iletişiminin, marka değerinin tüm alt boyutları üzerinde orta kuvvetin üzerinde pozitif yönde ve anlamlı ilişkisinin olduğu tespit edilmiştir. Tüm bu bilgiler doğrultusunda araştırma sorunsalı doğrultusunda belirlenen araştırma sorularına pozitif yönde cevaplar alınmıştır. Bu da göstermektedir ki bir GSM şirketinin sosyal medya iletişimi uygulamalarına yönelik başarısı ile tüketici temelli marka değer algısı arasında bir ilişki söz konusudur. Orta 
düzeyde olduğu sonucuna varılan bu ilişki, tüketici temelli marka değerinin tüm boyutları için de geçerlidir. Buradan hareketle tüketici temelli marka değerini artırmayı hedefleyen GSM şirketlerinin, her iki değişken arasındaki ilişki nedeniyle sosyal medya iletişimi için de gerekli yatırımları yapmaları ve etkin şekilde kullanmaları önem arz etmektedir. Çünkü aşağıda da sıralandığı üzere sosyal medya iletişimi ile tüketici temelli marka değeri arasındaki bu ilişki, diğer pek çok sektörde gözlemlendiği gibi GSM sektörü için de geçerlidir. Literatürde yer alan ve benzer sonuçlara ulaşılan bazı önemli çalışmalar aşağıda sunulmuştur:

Lüks markalar üzerine yapılan ve sosyal medya pazarlama çabalarının marka değerine ve tüketici davranışına etkisinin araştırıldığı bir çalışmanın sonucunda; sosyal medya pazarlama çabaları ve sonuçları (marka tercihi, fiyat primi ve sadakat) arasında pozitif bir ilişki bulunduğu sonucuna varılmıştır (Godey vd., 2016: 5833). Bir otele ait marka değerinin ölçümünde sosyal medya pazarlamasından faydalanılan bir çalışmanın sonucunda ise marka değeri alt boyutlarından biri olan marka farkındalığının, diğer tüm boyutlara ait ilişkilerin merkezinde yer aldığı görülmüştür (Callarisa vd., 2012: 77). Gümüş vd. (2013: 87) yaptıkları çalışmada Facebook uygulamalarının marka değeri üzerindeki etkisini araştırmışlar ve çalışmanın neticesinde; GSM Operatörünün Facebook sayfasında gerçekleştirdiği bilgilendirici ve eğlendirici ağızdan ağza iletişim ve müşteri ilişkileri uygulamalarının marka değeri boyutları (algılanan kalite, marka farkındalığ ve çağrışımları ile marka sadakati) üzerinde etkilerinin olduğunu belirlemişlerdir. Hanaysha (2016: 46) sosyal medya reklamlarının, marka değerinin tüm boyutları üzerinde belirgin bir pozitif etkisi olduğunu belirlemiştir. ETicaret şirketlerinin marka değerlerinin arttırılmasında sosyal medya pazarlamasının öneminin araştırıldığı deneysel bir çalışmada; online şirketlerin marka değerleri ile sosyal medya pazarlaması arasında önemli bir ilişki olduğu sonucuna varılmıştır (Kavisekera ve Abeysekera, 2016: 201). Marka iletişiminin marka değerine etkisini Facebook bağlamında değerlendiren bir çalışmanın sonuçları ise hem firma hem de kullanıcılar tarafından üretilen sosyal medya marka iletişiminin marka farkındalığını etkilediğini göstermiştir. Ayrıca kullanıcı tarafından üretilen sosyal medya marka iletişiminin marka sadakati ve algılanan marka kalitesi üzerinde pozitif yönde bir etkisinin olduğu görülmüştür (Schivinski ve Dabrowski, 2015: 31). As' ad ve Alhadid (2014: 315) yaptıkları çalışmada; Ürdünlü mobil servis sağlayıcıları için sosyal medya pazarlamasının boyutlarının marka değeri üzerinde istatistiksel olarak anlamlı bir etkisi olduğu sonucuna ulaşmışlardır.

Sosyal medya pazarlamasının, marka değerinin boyutlarından biri olan marka sadakati üzerindeki etkisi dikkat çekicidir. Daha geniş bir ifadeyle marka bilinci ve değer bilinci, sosyal medya pazarlaması ile marka sadakati arasındaki ilişkiye aracılık etmektedir (Ismail, 2017: 129). Can ve Çetin (2016: 885) sosyal medya pazarlamasından elde edilen faydaların, marka sadakatine etkisini araştırmışlar ve sonuçta; sosyal medya pazarlamasının fonksiyonel, sosyal ve maddi faydalarının bulunmasına karşın hedonik ve psikolojik fayda oluşturmadığı sonuçlarına ulaşmışlardır. Erdoğmuş ve Çiçek (2012: 1353) müşterilere ait marka sadakatinin; avantajlı kampanyalar düzenlendiğinde, uygun ve popüler içerikler sunulduğunda, markanın çeşitli platformlarda göründüğünde ve son olarak sosyal medya üzerinden uygulamalar gerçekleştirdiğinde olumlu yönde etkilendiği sonucuna ulaşmışlardır. Bu da marka değerinin boyutlarından biri olan marka sadakatinin oluşumunda sosyal medyanın etkisini göstermesi bakımından dikkat çekmektedir.

Şirketler tarafından düzenlenen sosyal medya faaliyetlerinin başarısı, tüketicilerin dikkatlerini çekebilmek ve onları bu faaliyetlere dahil edebilmekten geçmektedir. Bununla birlikte sosyal medya faaliyetlerine katılım toplumlar arasında farklılıklar gösterebilmektedir. Nitekim ABD'li ve Çin'li müşteriler üzerinde yapılan bir çalışmada sosyal medyaya katılım noktasında davranışsal olarak önemli farklılıkların bulunduğu görülmüştür (Jiao vd., 2018: 18). Çalışmada kollektivist ve dişa dönük tüketicilerin, sosyal medya katılımı yoluyla sosyal değeri tecrübe ettikleri, buna karşın bireysel ve içe dönük tüketicilerin ise içerik değerini önemsedikleri tespit edilmiştir. Çinli tüketicilerin daha fazla sosyal değere önem verdikleri, ABD li tüketicilerin ise içerik değerine daha fazla önem verdikleri bulunan sonuçlar arasındadır. Buna göre, sosyal değerin marka değeri üzerindeki etkisinin Çinli tüketiciler için daha güçlü olduğu söylenebilir.

Yapılan çalışmalarda büyük ölçüde sosyal medya pazarlaması bağlamında interaktif iletişimin marka değeri üzerindeki rolünün pozitif yönlü olduğu sonucuna ulaşılmışsa da olumsuz sonuçların bulunduğu istisnai çalışmalar da söz konusudur. Örneğin; Facebook üzerinden hızlı tüketim maddelerine yönelik yapılan bir çalışmada; firmanın ürettiği sosyal medya marka iletişiminin yalnızca 4 marka değeri boyutu (marka bilinci, marka algılamalı kalite, marka bilinirliği ve marka güvenliği) üzerinde doğrudan etkili olduğunu sonucuna ulaşılmıştır. Bir diğer sonuç ise kullanıcılar tarafından üretilen sosyal medya iletişiminin algılanan kalite, marka sadakati ve marka güveninde belirgin bir etkisinin olmadığıdır. Buna ek olarak, kullanıcı tarafından 
üretilen sosyal medya iletişiminin marka bilinirliği ve marka çağrışımı üzerinde olumsuz bir etkisi olduğu da bulunan sonuçlar arasındadır (Sadek vd., 2017: 237). Bir diğer çalışmada Colicev vd., (2018: 1) sosyal medyanın, müşteri tabanlı marka değeri üzerindeki etkilerini genel olarak güçlü bulmuşlarsa da hedonik ve yüksek katılımlı ürünlerin ticaretini yapan perakendecilerde sosyal medyanın müşteri tabanlı marka değerine zarar verdiğini tespit etmişlerdir.

Yapılmış olan araştırmalarda sosyal medya platformuna ait birçok farklı değişken ile marka değerine etki eden unsurlar arasındaki ilişkiler incelenmiştir. Bu çalışmadaki bulgular ile yapılmış olan birçok benzer araştırmanın sonuçları birbirine yakındır. Bu araştırmanın bulgularının, literatürde daha önce sosyal medya iletişiminin, marka değeri üzerindeki etkilerini tespit etmeye yönelik çalışmaların sonuçlarını destekleyici nitelikte olması ve bu iki değişken arasındaki ilişkiye yönelik Türkiye özelinde akademik bir çalışmanın yapılmamış olması, çalışmayı literatüre sağlayacağı katkılar nedeniyle önemli kılmaktadır. Yapılan çalışmanın, özellikle sosyal medya pazarlaması faaliyetlerine yönelik çalışan pazarlama profesyonelleri, konuya ilişkin akademik çalışmalarda bulunan akademisyenler ve şirketlerin marka değeri oluşumunda aktif rol oynayan yöneticiler başta olmak üzere çok sayıda kesime katkı sağlayacağı öngörülmektedir.

Yapılan çalışmada sosyal medya iletişimi ile tüketici temelli marka değeri arasındaki ilişki bir GSM şirketi özelinde ele alınmıştır. Bundan sonraki çalışmalarda ise; sosyal medya iletişimi ile diğer marka unsurları (finans temelli marka değeri vb.) arasındaki ilişki incelenebilir. Diğer yandan örneklem grupları referans alınarak çalışma farklı jenerasyonlar ya da farklı coğrafyalarda yaşayan tüketiciler üzerinde gerçekleştirilebilir.

\section{Kaynakça}

Aaker, D.A. (1992). Managing Brand Equity: Capitalizing on the Value of a Brand Name. Journal of Marketing, $56(2), 125-128$.

Aaker (2001). Strategic Market Management, New York, NY, John Wiley \& Sons, Inc.

Alam, M. and Khan, B. M. (2019). The Role of Social Media Communication in Brand Equity Creation: An Empirical Study. IUP Journal of Brand Management, 16(1), 54-78.

Alhaddad, A. A. (2015). The Effect Of Advertising Awareness On Brand Equity In Social Media. International Journal of e-Education, e-Business, e-Management and e-Learning, 5(2), 73-84.

As' ad, H. A. R., and Alhadid, A. Y. (2014). The Impact of Social Media Marketing on Brand Equity: An Empirical Study On Mobile Service Providers In Jordan. Review of Integrative Business and Economics Research, 3(1), 315-326.

Barefoot, D. and Szabo, J. (2010). Friends With Benefits A Social Media Merketing Handbook, No Strach Press.

Brogi, S. Calabrese, A. Campisi, D. Capece, G. Costa R. and Di Pillo, F. (2013). The Effects of Online Brand Communities on Brand Equity in the Luxury Fashion Industry. International Journal of Engineering Business Management Special Issue on Innovations in Fashion Industry, 5 (32), 1-9.

Callarisa, L., García, J. S., Cardiff, J., and Roshchina, A. (2012). Harnessing Social Media Platforms to Measure Customer-Based Hotel Brand Equity. Tourism Management Perspectives, 4, 73-79.

Campbell, D. E., and Wright, R. T. (2008). Shut-up I Don't Care: Understanding the Role of Relevance and Interactivity on Customer Attitudes Toward Repetitive Online Advertising. Journal of Electronic Commerce Research, 9(2), 62-76.

Can, P. ve Çetin, İ. (2016). Sosyal Medya Pazarlamasından Elde Edilen Faydaların Tüketici Marka Bağllığına Etkisi Üzerine Bir Araştırma. Atatürk Üniversitesi İktisadi ve İdari Bilimler Dergisi, 30(4), 885-906.

Colicev, A., Malshe, A. and Pauwels, K. (2018). Social Media and Customer-Based Brand Equity: An Empirical Investigation in Retail Industry. Administrative Sciences, 8(3), 1-16.

Coursaris, C. K., Van Osch, W. and Balogh, B. A. (2016). Do Facebook Likes Lead to Shares or Sales? Exploring the Empirical Links between Social Media Content, Brand Equity, Purchase Intention, And Engagement. In 2016 49th Hawaii International Conference on System Sciences (HICSS) (3546-3555). 


\section{M. Çakırkaya - M. Koçyiğit 11/3 (2019) 2027-2039}

Erdoğmuş, İ. E. and Cicek, M. (2012). The Impact of Social Media Marketing on Brand Loyalty. Procedia-Social and Behavioral Sciences, 58, 1353-1360.

Firat, D. ve Badem, A. C. (2008). Marka Değerleme Yöntemleri ve Marka Değerinin Mali Tablolara Yansitılmasi. Muhasebe ve Finansman Dergisi, (38), 210-219.

Fischer, E. ve Reuber, A. R. (2011). Social Interaction via New Social Media:(How) Can Interactions on Twitter Affect Effectual Thinking and Behavior? Journal of Business Venturing, 26(1), 1-18.

Godey, B., Manthiou, A., Pederzoli, D., Rokka, J., Aiello, G., Donvito, R., and Singh, R. (2016). Social Media Marketing Efforts of Luxury Brands: Influence On Brand Equity and Consumer Behavior. Journal of Business Research, 69(12), 5833-5841.

Gümüş, N. Zengin, H. ve Geçti, F. (2013). Sosyal Medya Aracı Olarak Facebook Uygulamalarının Marka Denkliği Üzerindeki Etkisi: Bir GSM Operatörünün Facebook Sayfası Üzerinde Araştırma. Sakarya İktisat Dergisi, 2 (2), 87-117.

Hanaysha, J. (2016). The Importance of Social Media Advertisements in Enhancing Brand Equity: A Study on Fast Food Restaurant Industry in Malaysia. International Journal of Innovation, Management and Technology, 7(2), 46-51.

Hanna, R., Rohm, A., and Crittenden, V. L. (2011). We're All Connected: The Power Of The Social Media Ecosystem. Business Horizons, 54(3), 265-273.

Ismail, A. R. (2017). The Influence of Perceived Social Media Marketing Activities on Brand Loyalty: The Mediation Effect of Brand and Value Consciousness. Asia Pacific Journal of Marketing and Logistics, 29(1), 129-144.

Jeong, E. and Jang, S. (2011). Restaurant Experiences Triggering Positive Electronic Word-Of-Mouth (E-WOM) Motivations. International Journal of Hospitality Management, 30, 356-366.

Jiao, Y., Ertz, M., Jo, M. S. and Sarigollu, E. (2018). Social Value, Content Value, and Brand Equity in Social Media Brand Communities: A Comparison of Chinese and US Consumers. International Marketing Review, 35(1), 18-41.

Kavisekera, S. ve Abeysekera, N. (2016). Effect of Social Media Marketing on Brand Equity of Online Companies. Management \& Marketing Journal, 14(2), 201

Kelly, L. (2007). Beyond Buzz: The Next Ceneration Of Word-Of-Mouth Marketing. New York. Amacom

Kietzmann, J. H., Hermkens, K., McCarthy, I. P. and Silvestre, B. S. (2011). Social Media? Get Serious! Understanding The Functional Building Blocks of Social Media. Business Horizons, 54(3), 241-251.

Kim, W., Jeong, O. R. and Lee, S. W. (2010). On Social Web Sites. Information Systems, 35, 215-236.

Koçak, A. ve Özer, A. (2004), Marka Değeri Belirleyicileri: Bir Ölçek Değerlendirmesi, 9. Ulusal Pazarlama Kongresi, 6-8 Ekim 2004, Ankara.

Laroche, M., Habibi, M. R., Richard, M. O. \& Sankaranarayanan, R. (2012). The Effects of Social Media Based Brand Communities on Brand Community Markers, Value Creation Practices, Brand Trust and Brand Loyalty. Computers in Human Behavior, 28, 1755-1767.

Mangold, W. G. and Faulds, D. J. (2009). Social media: The New Hybrid Element of the Promotion Mix. Business Horizons, 52(4), 357-365.

Nair, G. T. and Subramaniam, K. (2012). Transformation of Traditional Marketing Communications into Paradigms of Social Media Networking. In Asia Pacific Business Research Conference (13-14).

Nigam, A. (2012). Influence of Viral Marketing on Brand Equity Building with Reference To Online Social Networking Sites Networking Sites, IJCSMS International Journal of Computer Science \& Management Studies, 12 (1). $82-88$.

Schivinski, B. and Dabrowski, D. (2015). The Impact of Brand Communication on Brand Equity Through Facebook. Journal of Research in Interactive Marketing, 9(1), 31-53. 
M. Çakırkaya - M. Koçyiğit 11/3 (2019) 2027-2039

Sadek, H. Elwy, S. and Eldallal, M. (2017). The Impact of Social Media Brand Communication on ConsumerBased Brand Equity Dimensions Through Facebook in Fast Moving Consumer Goods: Egypt Case. The Business and Management Review, 8 (5), 237-251.

Samsunlu, G. ve Baş, M. (2016). Marka Değerinin Tüketici Satın Alma Tutumları Üzerine Etkisi ve McDonald's ve Burger King Üzerine Bir Araştırma. 15. Ulusal İşletmecilik Kongresi, 26-28 Mayıs 2016, İstanbul.

Seo, E. J. and Park, J. W. (2018). A Study on the Effects of Social Media Marketing Activities on Brand Equity and Customer Response In The Airline Industry. Journal of Air Transport Management, 66, 36-41.

Simon, C. J. and Sullivan, M. W. (1993). The Measurement and Determinants of Brand Equity: A Financial Approach. Marketing Science, 12(1), 28-52.

Stojanovic, I., Andreu, L. and Curras-Perez, R. (2018). Effects of the Intensity of Use of Social Media on Brand Equity: An Empirical Study in a Tourist Destination. European Journal of Management and Business Economics, 27(1), 83-100.

Taprial, V. and Kanwar, P. (2012). Understanding Social Media. Bookboon.

Taşkın, Ç. ve Akat, Ö. (2010). Tüketici Temelli Marka Değerinin Yapısal Eşitlik Modelleme ile Ölçümü ve Dayanıklı Tüketim Malları Sektöründe Bir Araştırma, İsletme ve Ekonomi Araştırmaları Dergisi, 1(2), 1-16.

Tsang, M. M., Ho, S. C. and Liang, T. P. (2004). Consumer Attitudes Toward Mobile Advertising: An Empirical Study. International Journal of Electronic Commerce, 8(3), 65-78.

Tuten, T.L. (2008). Advertising 2.0 Social Media Marketing in a Web 2.0 World. Westport-London: Praeger Publishers.

Ukkwatte, J. L. and Abeysekera, N. (2015). The Impact of Relationship Marketing on Brand Equity with Special Reference to Cinnamon Red Hotel in Sri Lanka. Management, Social Sciences and Humanities, 152-160.

Wright, B. K. (2015). Brand Communication Via Facebook: An Investigation of The Relationship Between The Marketing Mix, Brand Equity, and Purchase Intention in The Fitness Segment of The Sport Industry (Doctoral Dissertation, Indiana University).

Yoo, B. and Donthu, N. (2001). Developing and Validating a Multidimensional Consumer-Based Brand Equity Scale. Journal of Business Research, 52(1), 1-14.

Zahoor, S. Z. and Qureshi, I. H. (2017). Social Media Marketing and Brand Equity: A Literature Review. IUP Journal of Marketing Management; Hyderabad 16 (1), 47-64.

Zauner, A. Koller, M. and Fink, M. (2012). Sponsoring, Brand Value And Social Media. RAE, São Paulo, 52 (6), 681-691.

Zhang, C. B. and Lin, Y. H. (2015). Exploring Interactive Communication Using Social Media. The Service Industries Journal, (11-12). 670.

Türkiye'de İller Bazında Üniversite Öğrenci Sayılarının İl Nüfuslarına Oranı (2017-2018). https://www.drdatastats.com/turkiyede-iller-bazinda-universite-ogrenci-sayilarinin-il-nufuslarinaorani-2017-2018/, (Erişim Tarihi: 05.08.2019).

Social Brands. https://www.boomsocial.com/Social-Brands/2017/Agustos/Top100. (Erişim Tarihi: 18.09.2018). 